\title{
The semi-arid environment of Curaçao: a geochemical soil survey
}

\author{
A.J. de Vries ${ }^{1}$ \\ 1 Public Works The Hague, Department of Environment, P.O. Box 12651, 2500 DP \\ DEN HAAG, the Netherlands; e-mail: a.j.devries@dsb.denhaag.nl
}

Manuscript received: 9 April 1999; accepted in revised form: 9 June 2000

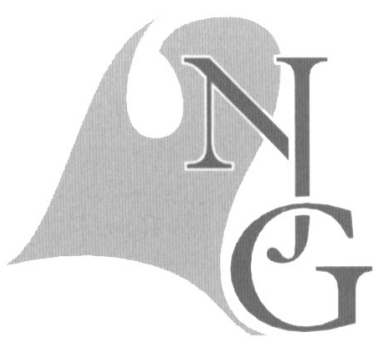

\begin{abstract}
A geochemical soil survey was carried out on the island of Curaçao in October 1992 as part of an overall geochemical characterisation of the three Leeward islands of the Netherlands Antilles. The aim of this soil survey was to provide systematic geochemical data of the rural soils of Curaçao for characterisation, geochemical mapping and environmental application. A total of 122 samples was collected from the topsoils (upper $0.1 \mathrm{~m}$ ) within a rectangular grid $\left(2 \mathrm{~km}^{2}\right)$. All samples were sieved to a grain size of $<2 \mathrm{~mm}$ and analysed for 24 elements by ICP-AES, after decomposition with hot aqua regia. A small, selected set of soil samples was subjected to a more extensive study of soil properties.

It appears from statistical data interpretation of the chemical compositions with techniques like non-linear mapping and cluster analysis that the topsoils of Curaçao can be divided into six homogeneous groups (soil types) with contrasting chemical signatures. Labelled according to their dominant geology, soil process or most striking characteristic, these soil types are defined as follows: sandy limestone soil type, Midden Curaçao soil type, arid/calcareous soil type, basalt West soil type, agriculture-influenced soil type, and the basalt East soil type.

Geochemical contour maps were made that provide a basis for environmental issues on the island. Finally, background levels (baseline data) were derived from the chemical soil composition of several elements, taking into consideration the correlation with the $\mathrm{Fe}$ or $\mathrm{Al}$ content of these soils. The defined baselines can be used to establish background values for future soil surveys.
\end{abstract}

Keywords: background values, environment, geochemical mapping, Netherlands Antilles

\section{Introduction}

Soils, plants, animals and humans interact in many different ways. Soils provide the basic materials, serve as an anchorage and a nutrient reservoir for plants and contain large groundwater resources. Much research has therefore been carried out to study and improve soils for agricultural purposes. From an environmental point of view, soil studies are focused on the appearance and distribution of elements in soils and groundwater. Geochemical variations of soil composition may be explained by variation of the soil or bedrock composition only, but can also be the result of other influences. Active geochemical and soil-forming processes, natural geochemical anomalies (caused by an ore body), climate and topography are some of the important natural factors that influence the element contents of soils. In addition to these factors, element contents can also be related to anthropogenic influence (external factors) like agricultural fertilizers or by accumulation of pollution.

Soil studies on the variation in geochemical compositions of soils are also of prime concern to the environment and therefore should discuss both natural 
and external factors for a better understanding. Recent geochemical baseline studies show that the determination and explanation of natural background levels (baseline data) of elements provides a useful tool for environmental policy (Salminen \& Tarvainen, 1997; De Vivo et al., 1997).

The aim of the present soil study is to provide systematic geochemical data of the soils of the semi-arid island of Curaçao for use in soil characterisation, geochemical mapping and environmental application. For data interpretation of the large data set from the analysis of the soil samples, a multivariate statistical method called 'cluster analysis' (FCM) will be used in combination with a pattern-recognition technique, non-linear mapping (NLM). Several groups of soil samples derived from these techniques are interpreted to identify the important active processes and factors that explain the characteristic chemistry of the distribution. As a result, these characteristic geochemical groups will be defined as soil types of $\mathrm{Cu}-$ raçao. The concentration ranges and distribution patterns of the various elements will be 'translated' into geochemical maps of the island. Finally, background levels (baseline data) for all soil types will be derived. From an environmental perspective, they provide an indication of expected 'background' levels of certain elements in a soil of Curaçao (uncontaminated soils) and may be used as baseline data according to soil samples in future.

\section{Previous soil surveys on Curaçao}

In an early soil survey on tropical-arid Curaçao, $\mathrm{Ha}$ milton (1941) made the following division of the soils:

- limestone red or limestone grey soils;

- volcanic soils of brown or grey sandy diorite soils;

- red/brown serpentine schist soils;

- alkaline salt soils.

The soils were classified as residual soils with large mineral reserves, for a great part caused by dry physical weathering. The water deficiency on the island was not only explained as a result of the arid climate but also by the porous structure and low clay and humus content of the soils. The red soils were described as having better drainage possibilities and higher contents of iron minerals and kaolinite. The grey soils were characterised by limited drainage; they contain more pyroxene and montmorillonite, and are rich in phosphate, carbonates and salts.

Based on a survey for a development plan on land and water (Grontmij \& Sogreah, 1968), a division was made into different soil and land types according to the geological subsoil and characteristics like texture and soil depth. The soils from the sampled areas were divided into three main groups:

- soils on limestone formation (nearly level);

- soils on diabases (nearly level - gently undulating);

- alluvial and colluvial soils.

The soils on limestone formations form about $28 \%$ of the total surface area. They are highly porous, generally shallow, and mostly saline. Their drainage system is different from those in non-calcareous formations. These soils are subdivided into the reddish soils and lagoonal soils of the lower depositional terrace. The soils on diabases (basalt) cover about $38 \%$ of the total surface. They form a low, undulating hilly land with plains. The soils range in thickness between about 0.1 and $0.4 \mathrm{~m}$. The surface is divided in several drainage basins that are drained by so-called 'roois' (STINAPA, 1977). The alluvial and colluvial soils are found in roois and plains. They are moderately deep, clayey and loamy soils. Variable amounts of black/brown silty soils occur at the surface; they contain a high percentage of clay (mostly montmorillonite). These soils have been classified as vertisols (Breteler, 1981).

The resulting soil and soil-potential maps of the island give an overview of the suitability of the soils for the various types of agricultural use (like soils suitable for irrigated agriculture, for grazing, etc.). In addition to the geological map of the island (Beets, 1972), this map has proven to be of particular value during fieldwork for the present geochemical study.

\section{Description of the soil-survey area}

\section{Geography}

Curaçao is one of the three Leeward Islands of the Netherlands Antilles, which are called the 'ABC islands' (Aruba, Bonaire and Curaçao). These islands are part of an island group called the 'Lesser Antilles', which are situated in the southern part of the Caribbean Sea off the coast of Venezuela. Geographically, the islands are located at about $12^{\circ} \mathrm{NL}$ and $70^{\circ}$ WL. Curaçao is an oblong island with a length of about $61 \mathrm{~km}$ and a width varying between 5 and 15 $\mathrm{km}$. The surface area of the island is approx. $450 \mathrm{~km}^{2}$.

\section{Geology}

The geology of the island of Curaçao is characterized by magmatic activity and mobility during Cretaceous and Early Tertiary (Beets, 1972; Beets \& MacGillavry, 1977). The stratigraphical base level is the $\mathrm{Cu}$ raçao Lava Formation (CLF), followed by the Knip Group, the Midden Curaçao Formation, and the limestones (Fig. 1). More than half of the island con- 


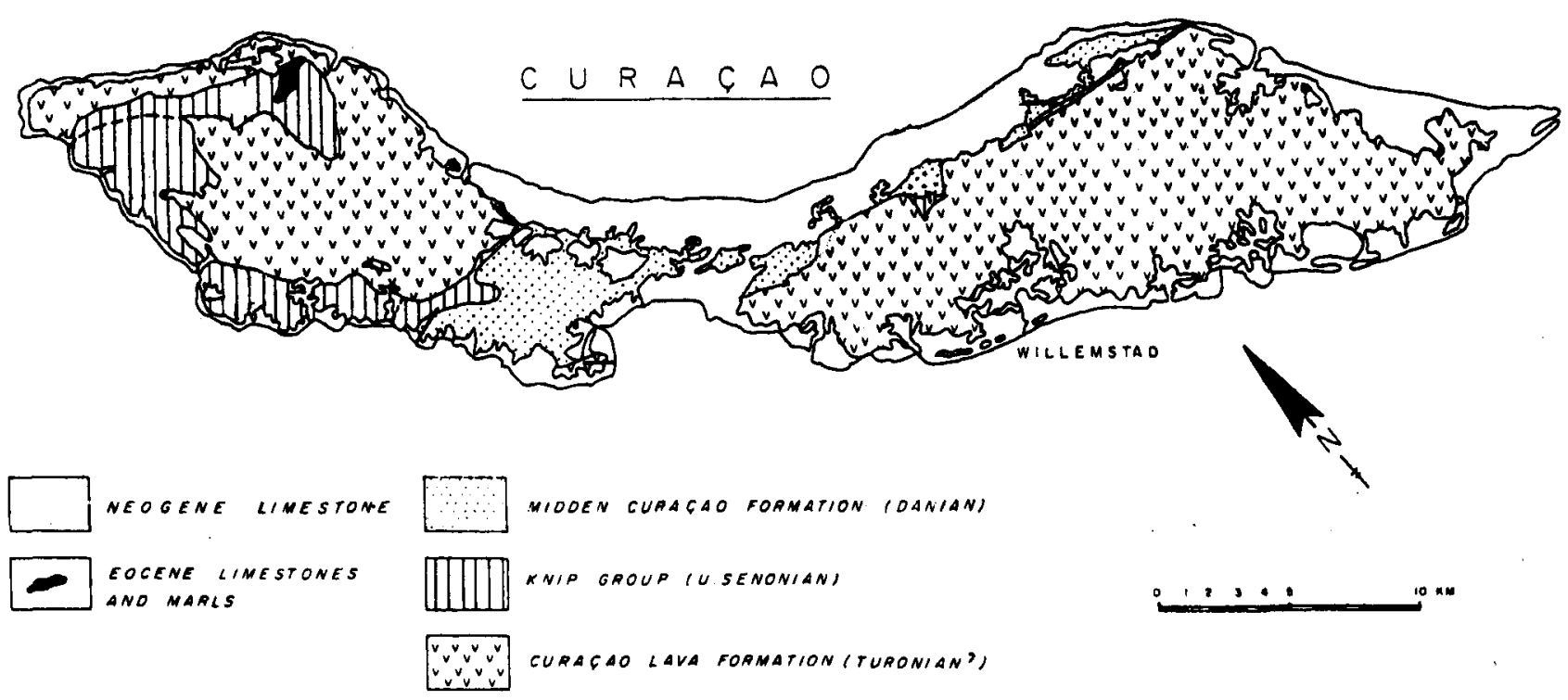

Fig. 1. Simplified geologic map of Curaçao (after Beets, 1972).

sists of two large anticlines of the Curaçao Lava Formation (NW and SE part of the island).

The Curaçao Lava Formation belongs to the group of low-potassium tholeites and is a submarine, extrusive succession of basalts with an anomalous thickness of more than $5 \mathrm{~km}$ (Klaver, 1980). A difference between the basaltic rocks of the northwestern and southeastern part of the island is the lack of picrites and variolitic tholeitic basalts in the northwestern part (Klaver, 1980). The basalts consist mainly of olivine, clinopyroxene, plagioclase and chlorite-like minerals. Deep weathering (regolith disintegration up to $15 \mathrm{~m}$ ) has to be attributed to former periods of a more humid climate than the present-day semi-arid climate (STINAPA, 1977). Strongly weathered basaltic rocks with recognizable characteristic pillow structures are exposed at the surface in several road cuts. Weathering at the surface has resulted in the production of a characteristic brownish-red coloured sandy to pebbly soil.

Stratigraphically, the Curaçao Lava Formation is followed by the Knip Group. They are separated by an unconformity. Before the Knip Group was deposited, the top of the basalts was strongly weathered, which is indicated by the appearance of in situ breccias. Important evidence for the conditions during this interval is the occurrence of shallow-water limestones (Zevenbergen and Casabao limestone lenses) on top of the Curaçao Lava Formation. The Knip Group consists almost entirely of pelagic and clastic, silica-rich sediments. It is a strongly non-homogeneous group that has been subdivided into nine subformations according to vertical and lateral facies changes.

The Midden Curaçao Formation (probably Danian) is a conformable succession, although consider- able submarine erosion may have taken place. It is exposed in the synclinorium of the central part of $\mathrm{Cu}$ raçao and on the northern side of the southeastern anticlinorium. In comparison to the Knip Group, it consists of more coarse detritus of conglomerates, sand and siltstones, and shales with little or no pelagic influence. It can be subdivided into two interfingering submarine fans.

The former formations are unconformably overlain by the Seroe Domi Formation, consisting of Neogene limestones, which mainly consist of accumulations of coral debris. The Neogene and Quaternary limestones were originally deposited as loose material, which became and consolidated and lithified under subaerial and/or submarine conditions, mainly through dissolution and recrystallisation of carbonates (STINAPA, 1977). Uplift in a number of steps during the first part of the Holocene is still evidenced by the seacut terraces at several levels (sea-breaker terraces). During this process of uplifting, a widespread system of valleys has evolved through erosion of first the inland limestones and secondly the easily weathered basalt core. The weathered detritus has been transported through the valley system towards the sea. In the more resistant limestone on the coast, narrow gorges arose that widened during the following subsidence into lagoons and bays. The limestones now surround the older formations in the core of the island and cover about a third of the total surface. They have been affected by uplift but not by folding.

\section{Mineralisation}

Some areas of the Quaternary limestones were altered into phosphate deposits as a result of local deposition 
of many phosphate-rich (fish remains) seabird excrements (guano) on top of the limestones. As a consequence of the presence of phosphoric acid in the solution after dissolution of the bird guano with rainwater, limestone was dissolved and $\mathrm{Ca}_{3}\left(\mathrm{PO}_{4}\right)_{2}$ precipitated. This process resulted finally in the formation of phosphate rocks. Rich phosphate deposits have been exploited on the island of Klein Curaçao (southeast of Curaçao) and from the table mountain, Santa Barbara, on Curaçao itself, which is also the highest elevation of the Neogene limestone (Stienstra, 1983).

On the western part of Curaçao (Sint Christoffelpark), remains of exploration workings can be found (copper and manganese mineralizations). These copper and manganese ores occur on the boundary of the Curaçao Lava Formation and the Knip Group, and are probably connected to in situ breccias and jasper lenses (Beets, 1972).

\section{Hydrogeology}

The main water source on the island consists of rainwater, which replenishes the groundwater storage. Aquifers on Curaçao are almost exclusively restricted to the weathered basaltic rocks. They are unconfined aquifers and therefore consist of phreatic groundwater. The depth of these weathered basalt layers varies between about 8 and $20 \mathrm{~m}$ below the surface. The difference in porosity between the weathered and the unweathered basalt is between 6 and $1 \%$. The total capacity of the groundwater is therefore low.

Water from the aquifers is available through dug and bored wells, and at some natural springs. Dug wells are commonly old wells at former plantations. Many windmills nowadays are present on the wells which, next to electric pumps, are still in use for pumping up groundwater. For collection of runoff rainwater and to improve the groundwater level, about 1200-1400 dams called 'fahas' have been built on the island. Many of these fahas are not well maintained and have lost their function.

\section{Soil formation}

Soils under semi-arid conditions are only infrequently moist, which results in slower and less intense weathering conditions. This is also reflected by the formation of shallow (soil depth: $25-50 \mathrm{~cm}$ ) and predominantly sandy textured soils (Young, 1976). Typical soils that may be formed from weathered basalt rocks are called 'red earths'. These soils are formed under conditions of moderate leaching and contain hematite and kaolinite, and montmorillonite as minor mineral.

Other basalt-derived soils are typified as black earths; they contain montmorillonite as dominant clay mineral, with minor amounts of hematite and kaolinite (Beckmann et al., 1974). These soils are formed at sites like depressions and show limited leaching and weathering, due to the low permeability of the dominant montmorillonitic clays. The simplified weathering process of basalt shows commonly the following stages:

$$
\begin{aligned}
& \text { primary minerals } \rightarrow \text { montmorillonite } \rightarrow \text { ferric } \\
& \text { oxides }+ \text { kaolinite }
\end{aligned}
$$

In most soils, $\mathrm{CaCO}_{3}$ and other soluble salts become mobilized by dissolution and weathering. They are subsequently transported from the soil profile by percolation of water. Under semi-arid conditions (evapotranspiration exceeds precipitation) with water supply and soluble salts, the evaporation is accompanied by an increase of salt concentration, which finally leads to precipitation and accumulation of mineral salts (salinization; Steila, 1976). If calcium and magnesium carbonates accumulate in the soil profile, this process is called 'calcification' (reversed weathering).

When the weathering processes of basic igneous rocks supply enough $\mathrm{Ca}^{2+}, \mathrm{Mg}^{2+}$, and $\mathrm{H}_{4} \mathrm{SiO}_{4}$ to the water drainage, secondary minerals such as calcite, smectite, dolomite, magnesite and sepiolite may be formed under these conditions ( $\mathrm{pH}$ values: 6.5-8.5; Van Breemen \& Brinkman, 1976). High concentrations of $\mathrm{HCO}_{3}^{-}$or $\mathrm{CO}_{3}{ }^{2-}$ may limit the $\mathrm{Ca}^{2+}$ level due to the precipitation of $\mathrm{CaCO}_{3}$.

\section{Climate}

The climate of Curaçao is semi-arid tropical (SAT). The rainfall is highly variable and falls mostly during the rainy season in heavy showers. The short and intensive rains cause erosion and runoff on the slopes of the hills. The mean annual precipitation is strongly influenced by a high evapotranspiration (about $85-95 \%$ of the precipitation), due to the strong trade winds on the island. The mean annual precipitation is approximately $574 \mathrm{~mm}$. An estimate of the runoff is about $10 \%$ of the precipitation. Estimates of underground flow towards the sea and replenishment of the groundwater are both $5 \%$ of the precipitation and are approx. $28.7 \mathrm{~mm}$ /year (Alam, 1977).

\section{Vegetation}

Because of the semi-arid climate, a desert-like vegetation is found on most parts of the island. It consists of dry woodland, cactus scrubs, several species of cactus, dry grasses and typical divi-divi trees. 


\section{Land use}

The agriculture on the island is of relatively small scale and is mostly situated on soils from the Curaçao Lava Formation, due to the presence of aquifers. There are two types of agriculture, depending on the water resource. The rain-dependant agriculture is limited and difficult because of a water shortage most of the year. Products are mainly cucumbers, water melons, ochra and beans. The other type is irrigated agriculture with, for example, a drip-irrigation system. The disadvantage of this type of agriculture is the effect of salt accumulation in the topsoil. Owing to this, many salt-resistant cocos palms are grown as agricultural products.

Approx. $10 \%$ of the island is occupied by urban or suburban area. The population of Curaçao is approx. 160,000 . The city of Willemstad forms the biggest agglomerate of urban area and is situated on the eastern part of the island.

\section{Sampling, sample preparation and geochemical analysis}

\section{Sampling}

The geochemical soil survey of Curaçao was carried out in October 1992. Soil samples were collected from all four main geological formations according to a systematic sampling plan. A square grid was defined over the island using 1:10,000 scale maps from the Cadastral Survey Department (KLM Aerokarto B.V., 1977/1982). The grid divided the surface into squares of 1 by $1 \mathrm{~km}$. One soil sampling site was randomly chosen per two squares(sample density of 1 per 2 $\mathrm{km}^{2}$; see Fig. 2 for sample locations). Preparation and analysis of the samples was finally carried out at the Institute of Earth Sciences of Utrecht University.

Samples were collected from the upper $0.1 \mathrm{~m}$ of the soil cover (top-soil samples). This chosen interval is most important from an environmental point of view. It has also been used in a background level study on Dutch soils in charge of the Department of Public Health and Environment (Edelman, 1983). The collection of soil material was performed with the use of a hand scoop. Ten (sub)samples were collected on each sampling site, according to the same procedure. The ten points for sampling were chosen randomly. After mixing the subsamples (in situ) by a coning and quartering method, one soil sample was taken. The area of one sampling site covers approx. $15 \times 15 \mathrm{~m}^{2}$. The soil-sampling sites were characterized in the field according to parameters like geology, topography, land use, (estimated) soil depth, soil colour, vegetation and amount of surface pollution.

Because of some hardly accessible areas and a large private property on the eastern side of the island (no access), not all planned samples could be collected. Finally, a total of 122 samples was taken. The soil samples were collected in plastic bags and stored after

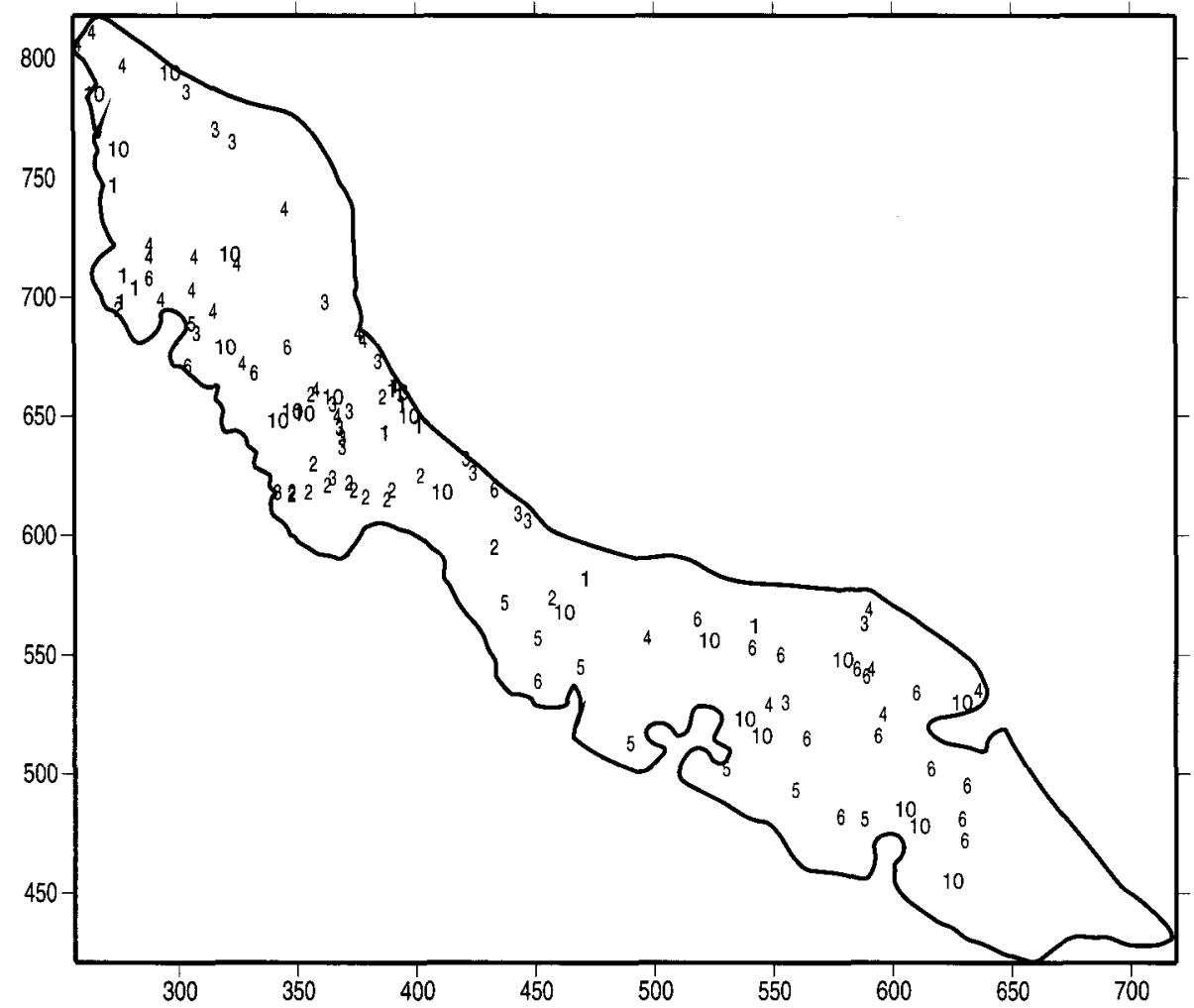

Fig. 2. Sample-location map with geographical distribution of the clusters (10 means non-classified) 
sieving in paper bags (dry) before ship transport to the Netherlands.

\section{Sample preparation}

A commonly used size range for soil samples in environmental studies is the $<2.0 \mathrm{~mm}$ fraction. All soil samples were therefore sieved to a grain size $<2.0$ $\mathrm{mm}$. The two fractions were weighted to determine the contribution of the $<2.0 \mathrm{~mm}$ fraction to the total weight of soil material.

\section{Geochemical analysis}

All soil samples were analysed by Inductively Coupled Plasma - Atomic Emission Spectrometry (ICPAES) after extraction with a hot mixture of concentrated $\mathrm{HCl}$ and $\mathrm{HNO}_{3}$ (ratio of 3:1, aqua regia). This extraction does not result in a release of the total amount of elements. It is used for soil-fertility research studies (concentrated acids and mixtures) in order to obtain an impression of the total recourse of nutrient important (trace) elements (Edelman, 1983). Trace elements incorporated in the most resistant minerals (in crystal lattices of primary silicate minerals) are not dissolved completely. The total amounts are, however, of minor interest for this soil survey. In the Netherlands, the aqua regia method is prescribed for routine environmental research (NEN standard 6465). Stiboka, for example, uses this method for certain elements ( $\mathrm{Cd}, \mathrm{Cu}, \mathrm{Ni}, \mathrm{Pb}$, and $\mathrm{Zn}$ ), and aqua regia for the analysis of heavy metals in sewage sludge (Hieltjens \& Breeuwsma, 1983). The following element levels of the soil samples were analysed by ICP-AES: Al, $\mathrm{Ba}, \mathrm{Be}, \mathrm{Ca}, \mathrm{Ce}, \mathrm{Co}, \mathrm{Cr}, \mathrm{Cu}, \mathrm{Fe}, \mathrm{K}, \mathrm{Li}$, $\mathrm{Mg}, \mathrm{Mn}, \mathrm{Na}, \mathrm{Ni}, \mathrm{P}, \mathrm{S}, \mathrm{Sc}, \mathrm{Ti}, \mathrm{Y}, \mathrm{Zn}$ and $\mathrm{Zr}$.

\section{Soil features}

In order to gain a better insight into the soil features and to investigate probable differences and relationships, a pilot set of soil samples (12) selected randomly within the geologic formations was subjected to several analyses. Within the five geological formations, three soil samples were from the limestone formation (two from the northern and one from the southern side of the island), two from the Knip Group, three from the Midden Curaçao Formation (one characterised as a salina soil, SAL), two from the Basalt East Formation and two from the Basalt West Formation. The following parameters have been analysed:

- grain-size distribution;

- clay-fraction $(<2 \mu \mathrm{m})$ (pipette method);

- soil $\mathrm{pH}$ (distilled water, $0.01 \mathrm{M} \mathrm{\textrm {CaCl } _ { 2 }}$ and $1 \mathrm{M}$ $\mathrm{KCl}$;

- soil electroconductivity (Ec of a soil/water mixture);

- carbonate content (Schleibler method);

- soil organic-carbon content (burning line method);

- clay-mineral identification (X-ray diffraction);

- electron probe micro-analysis (particle analysis).

The accuracy and precision of the analyses were monitored through the inclusions of blancs, duplicates and integrated reference materials in the analytical routine.

\section{Results and interpretation}

\section{Soil characteristics (pilot set)}

The results of the determined soil characteristics using a randomly selected pilot set of soil samples (12) are presented in Tables 1 and 2 . It appears from the

Table 1. Soil texture of the pilot-set soil samples.

\begin{tabular}{|c|c|c|c|c|}
\hline \multirow[t]{2}{*}{ sample number } & \multicolumn{3}{|c|}{ fraction (mass \%) } & \multirow{2}{*}{$\begin{array}{l}\text { soil classification } \\
\text { (after Steila, 1982) }\end{array}$} \\
\hline & $\begin{array}{l}\text { sand } \\
(50-2000 \mu m)\end{array}$ & $\begin{array}{l}\text { silt } \\
(2-50 \mu m)\end{array}$ & $\begin{array}{l}\text { clay } \\
(0-2 \mu m)\end{array}$ & \\
\hline $4.05 \mathrm{MC}$ & 28.0 & 62.8 & 9.2 & silt loam \\
\hline $13.02 \mathrm{MC}$ & 34.4 & 55.9 & 9.7 & silt loam \\
\hline 15.04Knip & 53.6 & 38.0 & 8.4 & sandy loam \\
\hline 19.02Knip & 34.4 & 52.2 & 13.4 & silty loam \\
\hline $11.08 \mathrm{LN}$ & 70.6 & 24.7 & 4.7 & sandy loam \\
\hline $16.01 \mathrm{LN}$ & 0.6 & 71.0 & 28.3 & silt clay loam \\
\hline $14.01 \mathrm{LS}$ & 41.6 & 46.2 & 12.2 & loam \\
\hline $2.02 \mathrm{BWW}$ & 31.4 & 53.0 & 15.6 & silt loam \\
\hline $10.01 \mathrm{BW}$ & 45.8 & 47.3 & 6.9 & loam \\
\hline $7.10 \mathrm{BE}$ & 52.0 & 40.9 & 7.1 & sandy loam \\
\hline $18.02 \mathrm{BE}$ & 59.0 & 33.0 & 8.0 & sandy loam \\
\hline 13.04SAL & 3.8 & 85.0 & 11.2 & silt loam \\
\hline
\end{tabular}


Table 2. pH, Ec, calcite and organic-carbon content of the pilot-set soil samples. $\mathrm{N}-\mathrm{d}=$ not determined.

\begin{tabular}{|c|c|c|c|c|c|c|}
\hline \multirow[t]{2}{*}{ sample number } & \multicolumn{3}{|c|}{$\mathrm{pH}$} & \multirow{2}{*}{$\frac{\mathrm{Ec}}{(\mathrm{mS} / \mathrm{cm})}$} & \multirow{2}{*}{$\frac{\text { carbonate }}{\text { (mass \%) }}$} & \multirow{2}{*}{$\frac{\text { organic carbon }}{(\text { mass } \%)}$} \\
\hline & water $^{l}$ & $\mathrm{CaCl}_{2}^{2}$ & $K C l^{3}$ & & & \\
\hline $4.05 \mathrm{MC}$ & 6.9 & 6.4 & 5.5 & 0.6 & 0.0 & 3.8 \\
\hline $13.02 \mathrm{MC}$ & 7.0 & 6.7 & 6.4 & 0.6 & 1.0 & 3.6 \\
\hline 15.04Knip & 6.4 & 5.7 & 5.5 & 0.1 & 0.0 & 0.3 \\
\hline $19.02 \mathrm{Knip}$ & 7.2 & 6.7 & 6.0 & 0.3 & $n-d$ & $\mathrm{n}-\mathrm{d}$ \\
\hline $11.08 \mathrm{LN}$ & 7.0 & 6.1 & 5.8 & 0.1 & 0.4 & $n-d$ \\
\hline $16.01 \mathrm{LN}$ & 8.3 & 7.7 & 7.0 & 1.1 & $\mathrm{n}-\mathrm{d}$ & 0.5 \\
\hline $14.01 \mathrm{LS}$ & 8.1 & 7.8 & 7.2 & 1.8 & 7.7 & 2.7 \\
\hline $2.02 \mathrm{BW}$ & 7.9 & 7.2 & 6.7 & 0.3 & 2.3 & 2.5 \\
\hline $10.01 \mathrm{BW}$ & 7.1 & 6.5 & 5.5 & 0.2 & 0.0 & 3.4 \\
\hline $7.10 \mathrm{BE}$ & 6.7 & 6.3 & 5.4 & 0.3 & 0.0 & 3.5 \\
\hline $18.02 \mathrm{BE}$ & $n-d$ & $\mathrm{n}-\mathrm{d}$ & $n-d$ & n-d & 0.1 & 2.7 \\
\hline 13.04SAL & 7.4 & 7.4 & 7.2 & 19.8 & 0.1 & 1.8 \\
\hline
\end{tabular}

$\mathrm{pH}$ in $25 \mathrm{ml}$ distilled water.

$2 \mathrm{pH}$ in $25 \mathrm{ml} \mathrm{CaCl}_{2}$ solution $(0.01 \mathrm{M})$.

${ }^{3} \mathrm{pH}$ in $25 \mathrm{ml} \mathrm{KCl}$ solution (1 M).

grain-size distribution that the soil texture ranges from sandy loam to silty-clayey loam soils. The average clay is about $10 \%$. The average soil $\mathrm{pH}$ in distilled water, $\mathrm{CaCl}_{2}$ solution $(0.01 \mathrm{M})$ and $\mathrm{KCl}$ solution $(1 \mathrm{M})$ is $7.3,6.8$ and 6.2 , respectively. These values indicate slightly alkaline to slightly acid soil conditions. The difference between these values is caused by the exclusion of $\mathrm{H}^{+}$ions adsorbed on the soil material due to the addition of $\mathrm{Ca}^{2+}$ or $\mathrm{K}^{+}$ions.

It is concluded from Ec measurements of soil and water mixtures that most soils have an Ec value between 0.3 and $0.8 \mathrm{mS} / \mathrm{cm}$. The carbonate content of the soil samples is commonly low, with the exception of one soil sample of limestone origin, due to visible fragments of calcite. The organic-carbon contents of the soils examined (average $2.5 \%$ ) are slightly higher than generally expected for top soils in semi-arid areas $(<1 \%$ due to rapid oxidation and slow plant growth; Young, 1976).

Kaolinite, montmorillonite and illite are the major identified clay minerals dominating the clay fraction of the pilot set of soil samples (Table 3). The hydrous mica, illite (non-expanding 2:1 type clay mineral), is formed under conditions similar to those leading to formation of montmorillonite, but the presence of $\mathrm{K}$ is essential. Their high stability is responsible for its abundance and persistence in soils (Loughnan, 1969). The expanding 2:1 type clay mineral, montmorillonite, is present in all four soil samples, with basalt as their parent material. This clay mineral is mostly found when soil conditions favour a slow removal of bases, and when $\mathrm{Mg}$ is present (Steila, 1976). Due to their shrink/swell characteristics, they may seal and shut soils when wet and therefore severely limit leaching and weathering processes (Beckmann et al., 1974). Kaolinite is the dominant 1:1 type clay mineral in almost each soil sample. This clay mineral may be formed through decomposition of montmorillonite, due to weathering processes.

Electron probe micro-analysis (microprobe) of thin sections of soil samples (Table 4) shows albite, anorthite and quartz as the dominant primary minerals. The main identified secondary minerals are smectite, kaolinite and hematite. These are expected secondary minerals for soils derived from basaltic bedrock (Beckman et al., 1974). Albite and anorthite are representative minerals for many soils where limited wa-

Table 3. Silicate clay minerals from the clay fraction identified with $\mathrm{X}$-ray diffraction.

-: not present; +: low peak (trace); ++: dominant peak.

\begin{tabular}{lllll}
\hline $\begin{array}{l}\text { sample } \\
\text { number }\end{array}$ & illite & kaolinite & $\begin{array}{l}\text { montmo- } \\
\text { rillonite }\end{array}$ & vermiculite \\
\hline $4.05 \mathrm{MC}^{1}$ & - & - & - & - \\
$13.02 \mathrm{MC}$ & ++ & + & - & - \\
$15.04 \mathrm{Knip}$ & ++ & ++ & - & - \\
$19.02 \mathrm{Knip}$ & + & ++ & - & - \\
$11.08 \mathrm{LN}$ & ++ & ++ & - & - \\
$16.01 \mathrm{LN}$ & - & ++ & - & ++ \\
$14.01 \mathrm{LS}$ & $\mathrm{x}$ & ++ & ++ & - \\
$2.02 \mathrm{BW}$ & ++ & ++ & ++ & - \\
$10.01 \mathrm{BW}$ & - & - & ++ & - \\
$7.10 \mathrm{BE}$ & - & - & ++ & - \\
$18.02 \mathrm{BE}$ & ++ & ++ & ++ & - \\
$13.04 \mathrm{SAL}$ & - & ++ & - & ++ \\
& & & & \\
\hline
\end{tabular}

${ }^{1}$ almost no peaks could be distinguished (amorphous material).

2 probably nontronite (reflection at $13.4 \AA$ ). 
Table 4. Minerals identified with electron-probe micro-analysis. Because many but not all soil particles of a sample have been analysed, the identified primary and secondary minerals have to be considered as an indication of the dominant minerals present.

\begin{tabular}{lll}
\hline sample number & primary minerals & secondary minerals \\
\hline $4.05 \mathrm{MC}$ & albite & smectite \\
$13.02 \mathrm{MC}$ & albite, quartz & kaolinite \\
$15.04 \mathrm{Knip}$ & quartz & illite, smectite \\
$19.02 \mathrm{Knip}$ & quartz & kaolinite \\
$11.08 \mathrm{LN}$ & albite, quartz & apatite, hematite \\
$16.01 \mathrm{LN}$ & - & illite \\
$14.01 \mathrm{LS}$ & quartz & calcite, magnesite, smectite \\
$2.02 \mathrm{BW}$ & albite, quartz & calcite, kaolinite, smectite, hematite \\
$10.01 \mathrm{BW}$ & anorthite, quartz & smectite \\
$7.10 \mathrm{BE}$ & albite, anorthite & smectite, hematite \\
$18.02 \mathrm{BE}$ & albite & kaolinite, smectite \\
$13.04 \mathrm{SAL}$ & quartz & illite \\
\hline
\end{tabular}

ter keeps chemical weathering at a low stage. In contrast, kaolinite and hematite are associated with soils characterised as having an advanced weathering stage (Mitchell, 1982). The identified primary minerals have sufficient chemical durability to persist the weathering processes. The iron speciations of the selected soil samples are presented in Table 5 .

The present investigation of the iron speciation of Curaçao soils is a preliminary study. Nevertheless, iron speciation of these soils indicates a low weathering stage, since most $\mathrm{Fe}$ is still present in another form than oxides (probably silicates). Fe that does occur in oxides is, however, mostly present as the less reactive, more residual crystalline form. About $5 \%$ of the total iron is in an amorphous form present in soils. The two highest values of amorphous iron in the soil samples of the Midden Curaçao Formation indicate that these soils are slightly more vulnerable to weathering than the other soils sampled.

\section{General chemical soil composition}

The general chemical soil composition of the $\mathrm{Cu}$ raçao soils is presented in Table 6 . These soils are characterized by $\mathrm{Fe}, \mathrm{Al}, \mathrm{Ca}$ and $\mathrm{Mg}$ as major components, and by $\mathrm{K}, \mathrm{Na}, \mathrm{Ti}$, and $\mathrm{Mn}$ contents as important minor components. High heavy-metal contents (especially $\mathrm{Cr}, \mathrm{Ni}, \mathrm{Zn}$ and $\mathrm{Cu}$ ) are also characteristic of Curaçao soils.

\section{Data analysis and geochemical classification of soils}

\section{Data analysis}

A multivariate data analysis technique, fuzzy c-means clustering (FCM), was used to find agglomerations of soil samples that are mutually related in their geochemical and/or active soil processes. FCM clustering uses a concept of fuzziness, which results in a kind of

Table 5. Iron speciation of soil samples (fraction $<2 \mathrm{~mm}$ ). Total $\mathrm{Fe}$ is the total amount of iron present in the samples as determined by ICPAES after a HF-perchloric acid extraction; amorphous $\mathrm{Fe}$ is estimated as oxalate-extracted Fe; crystalline Fe is estimated as the dithionite-extracted $\mathrm{Fe}$ in excess of the oxalate-extracted $\mathrm{Fe} . \mathrm{n}-\mathrm{d}=$ not determined.

\begin{tabular}{llll}
\hline sample number & $\begin{array}{l}\text { total Fe } \\
(\text { mass \%) }\end{array}$ & $\begin{array}{l}\text { amorphous Fe } \\
(\% \text { of total } \mathrm{Fe})\end{array}$ & $\begin{array}{l}\text { Fe in crystalline iron oxides } \\
\text { (\% of total Fe) }\end{array}$ \\
\hline $4.05 \mathrm{MC}$ & 3.0 & 16.0 & $\mathrm{n}-\mathrm{d}$ \\
$13.02 \mathrm{MC}$ & 4.7 & 5.8 & 38 \\
$15.04 \mathrm{Knip}$ & 5.2 & 7.0 & $\mathrm{n}-\mathrm{d}$ \\
$19.02 \mathrm{Knip}$ & 3.0 & 7.9 & 29 \\
$11.08 \mathrm{LN}$ & 8.8 & 0.6 & 26 \\
$16.01 \mathrm{LN}$ & 7.9 & 4.2 & $\mathrm{n}-\mathrm{d}$ \\
$14.01 \mathrm{LS}$ & 4.4 & 4.0 & $\mathrm{n}-\mathrm{d}$ \\
$2.02 \mathrm{BW}$ & 3.4 & 6.9 & $\mathrm{n}-\mathrm{d}$ \\
$10.01 \mathrm{BW}$ & 8.9 & 4.5 & $\mathrm{n}-\mathrm{d}$ \\
$7.10 \mathrm{BE}$ & 7.0 & 3.4 & $\mathrm{n}-\mathrm{d}$ \\
$18.02 \mathrm{BE}$ & 8.0 & 1.2 & 13.0 \\
$13.04 \mathrm{SAL}$ & 5.1 & 10.0 & \\
\hline
\end{tabular}


Table 6. General chemical compostion of Curaçao soils. The major elements are in mass $\%$, the minor elements are in ppm.

\begin{tabular}{|c|c|c|c|c|}
\hline element & median $^{1}$ & $68 \%$ interval $^{1}$ & $\begin{array}{l}\text { mini- } \\
\text { mum }\end{array}$ & $\begin{array}{l}\text { maxi- } \\
\text { mum }\end{array}$ \\
\hline \multicolumn{5}{|c|}{ major elements } \\
\hline $\mathrm{Al}$ & 4.4 & $2.9-5.9$ & 0.8 & 7.4 \\
\hline $\mathrm{Ti}$ & 0.26 & $0.08-0.44$ & 0.002 & 0.70 \\
\hline $\mathrm{Fe}$ & 5.6 & $4.0-7.3$ & 1.4 & 9.0 \\
\hline $\mathrm{Mn}$ & 0.11 & $0.07-0.15$ & 0.025 & 0.25 \\
\hline $\mathrm{Ca}$ & 1.4 & $0.5-4.1$ & 0.1 & 25 \\
\hline $\mathrm{Mg}$ & 1.9 & $1.1-2.8$ & 0.1 & 4.7 \\
\hline $\mathrm{Na}$ & 0.01 & $0.03-0.32$ & 0.007 & 1.5 \\
\hline $\mathrm{K}$ & 0.35 & $0.19-0.65$ & 0.076 & 1.9 \\
\hline \multicolumn{5}{|c|}{ minor elements } \\
\hline $\mathrm{Ba}$ & 52 & $19-145$ & 11 & 1200 \\
\hline $\mathrm{Be}$ & 1.6 & $0.96-2.5$ & 0.52 & 5.6 \\
\hline $\mathrm{Ce}$ & 12 & $8.0-18$ & 3.5 & 50 \\
\hline Co & 25 & $15-34$ & 5.8 & 45 \\
\hline $\mathrm{Cr}$ & 200 & $100-290$ & 24 & 420 \\
\hline $\mathrm{Cu}$ & 10 & $62-140$ & 18 & 200 \\
\hline $\mathrm{Li}$ & 10 & $4.9-22$ & 1.9 & 56 \\
\hline $\mathrm{Ni}$ & 109 & $59-160$ & 6 & 290 \\
\hline $\mathrm{P}$ & 32 & $180-570$ & 115 & 2000 \\
\hline $\mathrm{S}$ & 240 & $150-380$ & 74 & 1300 \\
\hline $\mathrm{Sc}$ & 2 & $15-40$ & 5.2 & 54 \\
\hline $\mathrm{Y}$ & 14 & $9.3-21$ & 3.1 & 36 \\
\hline $\mathrm{Zn}$ & 92 & $64-130$ & 37 & 580 \\
\hline $\mathrm{Zr}$ & 1 & $8.1-30$ & 0.5 & 50 \\
\hline
\end{tabular}

1 Estimates based on the assumption of a normal distribution or in the case of $\mathrm{Ca}, \mathrm{Na}, \mathrm{K}, \mathrm{Ba}, \mathrm{Be}, \mathrm{Ce}, \mathrm{Li}, \mathrm{P}, \mathrm{S}, \mathrm{Y}$ and $\mathrm{Zn}-\mathrm{a} \log -$ normal distribution.

measure of similarity between the sample and clusters. With FCM clustering, the similarity between samples and clusters is described with a membership, which varies between one (exactly similar) and zero (completely different). The total sum of memberships assigned to each of the distinct clusters, is for each individual sample equal to one. Samples in a position intermediate between two clusters can be recognised by similarity in the assigned memberships. This sort of overlap between clusters is often found in geochemistry, and therefore favours the application of the FCM clustering. Outliers in chemical composition of the soil samples were detected by approximately the same assignment of memberships to each cluster of the model.

Elements selected as parameters for the FCM clustering were: $\mathrm{Al}, \mathrm{Fe}, \mathrm{Ca}, \mathrm{Mg}, \mathrm{P}, \mathrm{K}, \mathrm{Sc}, \mathrm{Ti}, \mathrm{V}, \mathrm{Cr}, \mathrm{Mn}$, $\mathrm{Ni}$ and $\mathrm{Zr}$. This set of elements was selected because it comprises major mineral-forming elements, like $\mathrm{Al}$, $\mathrm{Fe}, \mathrm{K}, \mathrm{Ca}$ and $\mathrm{Mg}$, and trace elements that were expected to be least sensitive to pollution. Prior to the clustering procedures, histograms (frequency diagrams) were studied to determine whether the statis- tical distribution pattern of the elements was similar to a normal or a log-normal distribution. Interpretation of the data analysis has resulted into a geochemical classification of the soils.

\section{Geochemical classification of soils}

A 6-cluster model was selected for further interpretation. The definition of six geochemical soil types (homogeneous groups of soils) was determined on the basis of best fit between interpretation of the characteristic chemical composition of each cluster of soils and geochemical, soil-forming or external factors, in combination with the NLM plot. The geochemical soil types have been labelled according to the most striking characteristic (like element content, dominant geology, and soil process). The characteristic geochemical soil types of Curaçao resulting from FCM clustering (with 13 elements) are presented in Table 7. Figure 2 gives the geographical distribution of the clusters. The chemical composition of the classified soil types with contrasting chemical signatures is presented in abundance plots for the elements. Characteristics and interpretation of these soil types are given below.

\section{Sandy limestone soil type [SL]}

The SL soil type includes soil-sampling sites from the limestone formation (67\%) and from the Knip Group (33\%). This soil type is geochemically characterised by the lowest concentrations of virtually all elements, with the exception of $\mathrm{Ti}, \mathrm{K}$ and $\mathrm{P}$. Low $\mathrm{Al}$ and $\mathrm{Fe}$ contents (Fe/Al ratio of 1.7) are combined with low levels of trace elements. This indicates minerals that are resistant to acid extraction and/or weathering processes. The clay content and the amount of iron minerals are probably low as well. In combination with texture and low organic-matter content, this soil type does not hold water supply and/or much plant nutrients. Another characteristic of this soil type is the low content of the relatively immobile elements like $\mathrm{Ti}, \mathrm{Cr}$ and Sc. With the exception of two outliers (highly calcareous rock soils from the middle Limestone terrace) this soil type contains low levels of the mobile elements $\mathrm{Ca}$ and $\mathrm{Mg}$. The SL soil type is mostly orange brown with a sandy texture.

\section{Midden Curaçao soil type [MC]}

The MC soil type is characterised by a higher $\mathrm{Al}, \mathrm{Fe}$, $\mathrm{Ca}, \mathrm{Mg}$ and $\mathrm{K}$ content. The amounts of $\mathrm{Ti}$ of this soil type and the SL soil type are both relatively low. The $\mathrm{Fe} / \mathrm{Al}$ ratio (1.4) is slightly lower. The $\mathrm{Ni}, \mathrm{V}, \mathrm{K}, \mathrm{Zn}$ and $\mathrm{Li}$ contents are about a factor two higher than in the SL soil type. The combination of the occurrence 
Table 7. Chemical composition of the soil types (cluster centres) of Curaçao. The major elements are shown in mass \%, the minor elements in ppm.

$\mathrm{SL}=$ sandy limestone soil type. $\mathrm{MC}=$ Midden-Curaçao soil type. $\mathrm{AC}=$ arid/calcareous soil type. $\mathrm{BW}=\mathrm{Basalt}$ West soil type. $\mathrm{AI}=$ agriculture-influenced soil type. $\mathrm{BE}=$ Basalt East soil type.

\begin{tabular}{|c|c|c|c|c|c|c|}
\hline element & $\begin{array}{l}\text { SL } \\
\text { cluster } 1\end{array}$ & $\begin{array}{l}\mathrm{MC} \\
\text { cluster } 2\end{array}$ & $\begin{array}{l}\text { AC } \\
\text { cluster } 3\end{array}$ & $\begin{array}{l}\text { BW } \\
\text { cluster } 4\end{array}$ & $\begin{array}{l}\text { AI } \\
\text { cluster } 5\end{array}$ & $\begin{array}{l}\mathrm{BE} \\
\text { cluster } 6\end{array}$ \\
\hline \multicolumn{7}{|c|}{ major elements } \\
\hline $\mathrm{Al}$ & 1.8 & 3.2 & 4.3 & 5.1 & 5.2 & 5.7 \\
\hline $\mathrm{Ca}$ & 1.9 & 1.0 & 2.0 & 2.0 & 4.1 & 2.7 \\
\hline $\mathrm{Fe}$ & 2.9 & 4.3 & 5.4 & 7.3 & 5.8 & 6.5 \\
\hline $\mathrm{Mg}$ & 0.6 & 1.3 & 2.0 & 2.0 & 3.0 & 2.6 \\
\hline \multicolumn{7}{|c|}{ minor elements } \\
\hline $\mathrm{Cr}$ & 83 & 97 & 192 & 212 & 270 & 300 \\
\hline $\mathrm{K}$ & 2850 & 4950 & 4630 & 3980 & 3000 & 2160 \\
\hline $\mathrm{Mn}$ & 703 & 952 & 974 & 1480 & 1040 & 1290 \\
\hline $\mathrm{Ni}$ & 45 & 86 & 96 & 94 & 151 & 149 \\
\hline$P$ & 280 & 388 & 320 & 285 & 730 & 225 \\
\hline $\mathrm{Sc}$ & 7 & 13 & 25 & 38 & 30 & 36 \\
\hline $\mathrm{Ti}$ & 360 & 112 & 2165 & 4060 & 3025 & 3425 \\
\hline V & 67 & 98 & 161 & 232 & 160 & 160 \\
\hline $\mathrm{Zr}$ & 9 & 9 & 17 & 26 & 18 & 25 \\
\hline
\end{tabular}

of high levels of the slightly mobile element $\mathrm{K}$, together with low levels of the immobile element $\mathrm{Ti}$, is probably due to the large contents of 'unweathered' primary minerals like K-feldspar. This soil type contains also the maximum amounts of $\mathrm{Ba}, \mathrm{Zn}$ and $\mathrm{Li}$. The light weathering status of these soils is also supported by the high amounts of rocks in the top soils observed during the fieldwork.

\section{Arid/calcareous soil type [AC]}

This soil type is geochemically characterized by an approximately twice as high content of the mobile elements $\mathrm{Ca}$ and $\mathrm{Mg}$ than present in the $\mathrm{MC}$ soil type. Another characteristic is the higher content of the elements $\mathrm{Fe}, \mathrm{Al}, \mathrm{Cr}, \mathrm{Sc}$ and of the mobile element $\mathrm{Na}$. A striking feature is the approximately ten times higher Ti level than present in the SL and MC soil types. The AC soil type might therefore be characterized as being more weathered than the SL and MC types. The high $\mathrm{K}$ content can be the result of an 'immobilisation' in illite clays and/or other Al-silicates (Sposito, 1989). This is also reflected by an association between the $\mathrm{K}$ and $\mathrm{Al}$ contents. The abundance plot of $\mathrm{Ba}$ shows that the Ba levels in this soil type cover a wide range. This can be explained by the presence of two samples, which contain high $\mathrm{Ba}$ levels. The $\mathrm{Ca}$ and $\mathrm{Mg}$ levels of these soils are mainly the same as in the Basalt West soil type. Other differences in comparison to the Basalt West soil type (see below) is the much lower level of the major element $\mathrm{Fe}$, and therefore lower levels of the trace elements $\mathrm{Cu}$ and $\mathrm{Co}$ as well. According to the other defined soil types of Curaçao, this type takes an intermediate position of element levels, with the exception of the $\mathrm{K}, \mathrm{Li}$, and $\mathrm{Ba}$ content.

\section{Basalt West soil type [BW]}

The BW soil type contains the highest amount of extracted $\mathrm{Fe}$ and $\mathrm{Ti}$, together with the highest amounts of the trace metals $\mathrm{Mn}, \mathrm{V}, \mathrm{Co}, \mathrm{Cu}, \mathrm{Sc}, \mathrm{Y}$ and $\mathrm{Be}$. In comparison to the other soil types, this is an indication of different parent material and/or conditions of weathering. The $\mathrm{Fe} / \mathrm{Al}$ ratio of this soil type is about 1.4. A clear association is found between the contents of $\mathrm{Co}$ and $\mathrm{Mn}$. The abundance plot of $\mathrm{Ba}$ shows a relatively low level for this soil type, which is similar to that in the AI and BE soil types (see last soil type). To obtain an indication of the level of trace-metal concentrations in the Curaçao soils, a comparison of the $\mathrm{Cu}$ contents of these soils with the Dutch A, B and C values for soils has been made. It appears that the $\mathrm{Cu}$ content exceeds the Dutch $\mathrm{B}$ value for soils. The $\mathrm{Cu}$ content shows an affinity for the Fe content, which is also indicated by a clear general correlation between these two elements (see Table 8). This affinity can be related to an isomorphic substitution for $\mathrm{Fe}$ and $\mathrm{Mg}$ in olivines, or pyroxenes, or a specific adsorption of $\mathrm{Cu}$ on the surface of Fe-(hydr)oxide groups (Sposito, 1989). There is no clear association between the $\mathrm{Cu}$ and $\mathrm{Al}$ contents. A strong affinity is found between the high $\mathrm{V}$ and Fe content of these soils. There seems to be no clear association between the contents of the mobile elements $\mathrm{Ca}, \mathrm{Mg}, \mathrm{Na}$ and $\mathrm{K}$, with the $\mathrm{Al}$ content for this soil type (possibly as a result of relatively 
Table 8. Baselines for soils of Curaçao: a framework for the identification of soil contamination.

\begin{tabular}{lccc}
\hline Elementent & $\begin{array}{l}\text { correlation } \\
\text { coeffecient }(\mathbf{r})\end{array}$ & baseline regression & $\begin{array}{c}\text { standard error of estimate times 2 } \\
\text { (precision interval) }\end{array}$ \\
\hline $\mathrm{Co}$ & 0.91 & $-5.1+5.3 \mathrm{Fe}$ & 7.8 \\
$\mathrm{Cu}$ & 0.88 & $-17.8+21.0 \mathrm{Fe}$ & 37.9 \\
$\mathrm{~V}$ & 0.78 & $-37.6+35.3 \mathrm{Fe}$ & 93.4 \\
$\mathrm{Ba}$ & -0.28 & $243-25.8 \mathrm{Fe}$ & 290 \\
$\mathrm{Zn}$ & 0.24 & $71.7+4.1 \mathrm{Fe}$ & 54.9 \\
$\mathrm{Cr}$ & 0.75 & $-10.0+46.6 \mathrm{Al}$ & 127.4 \\
$\mathrm{Ni}$ & 0.60 & $23.6+19.2 \mathrm{Al}$ & 78.6 \\
\hline
\end{tabular}

high amounts of primary Al-minerals). Influence of calcification processes may also have affected the amounts of $\mathrm{Ca}$ and $\mathrm{Mg}$ present, despite of the amounts adsorbed by clays in these soils.

\section{Agriculture-influenced soil types [AI]}

This soil type is an anthropogenically (agriculture) influenced soil type. The influence of external factors like irrigation and use of fertilizers and/or manure is reflected by high contents of elements like $\mathrm{P}, \mathrm{Ca}, \mathrm{Mg}$, $\mathrm{Na}$, and $\mathrm{Sr}$. Other elements that occur in high concentrations are $\mathrm{Ni}$ and $\mathrm{S}$. Addition of $\mathrm{P}$ to calcareous soils may lead to a quick revert of $\mathrm{P}$ into insoluble forms (Young, 1976). The high Sr content can be explained by the process of coprecipitation of $\mathrm{Sr}$ with sulphate (Beets \& MacGillavry, 1977). The high $\mathrm{Na}$ content is probably due to the influence of the salinization process, caused by the additional supply of water by irrigation.

\section{Basalt East soil types [BE]}

The BE soil type is characterized by the highest levels of the element $\mathrm{Al}$ and trace elements $\mathrm{Cr}$ and $\mathrm{Ni}$. The lowest $\mathrm{Fe} / \mathrm{Al}$ ratio (1.1) indicates the relative increase of the Al content, due to Al minerals in these soil types. Significant levels of the trace element $\mathrm{Co}$ and of the mobile elements $\mathrm{Ca}$ and $\mathrm{Mg}$ were also found. The high amounts of these earth alkalis are probably caused by low leaching conditions (Sposito, 1989). These elements may still be present in the primary minerals, as weathering products of hydrolyzation reactions, or being supplied to the area with flows of surface water during the rainy season. The dominance of a common process is also indicated by the small range of the variation in the $\mathrm{Ca}$ content for this soil type. The soils are probably influenced by redistribution and reversed weathering processes of soluble minerals in the soil. The highest Al content for this soil type is found in combination with an alkaline environment.

\section{Geochemical mapping and background levels (baseline data)}

\section{Geochemical mapping}

The soil data have been used to produce geochemical maps of the island Curaçao with the objective to get an impression of the distribution of the elements in these soils. Geochemical maps display the geographical distribution of the major, minor and trace element levels in soils or rocks. For example, anomalies of certain elements may be a guide for mineral exploration. A different useful application of these maps can be for environmental purposes. Important indications of pollution or the occurrence of high natural backgrounds can be deduced from the (natural) distribution of some heavy metals in soils. The geochemical maps of Curaçao have been produced according to inverse distance on the soil data. A selection of geochemical maps is presented in Figure 3.

The geochemical map of the major element, $\mathrm{Al}$ (Fig. 3a), gives an indication of the presence of secondary minerals like montmorillonite and kaolinite and of primary silicate minerals in the soils of $\mathrm{Cu}$ raçao. It appears from the $\mathrm{Al}$ distribution pattern that these minerals are most abundant on the southeastern part of the island. Maps of the trace elements, $K$ and $\mathrm{Li}$, present both a concentrated area in the middle part of Curaçao. The $\mathrm{K}$ levels are highest in soils from limestone origin along the north coast and indicate influence by sea salt deposits.

The geochemical map of the trace element, $\mathrm{Ba}$ (Fig. 3b), shows higher Ba levels in soils derived from Basalt West in the northwestern part of the island. They may be related to small hematite and Cu mineralizations that are found on the boundary between the Knip Group (St. Christoffel Member) and the Curaçao Lava Formation (Beets, 1972). A possible explanation for the high levels of $\mathrm{Ba}$ is early hydrothermal activity, which may have resulted in enrichment in Ba.

The geochemical map of the element Ti reflects the 

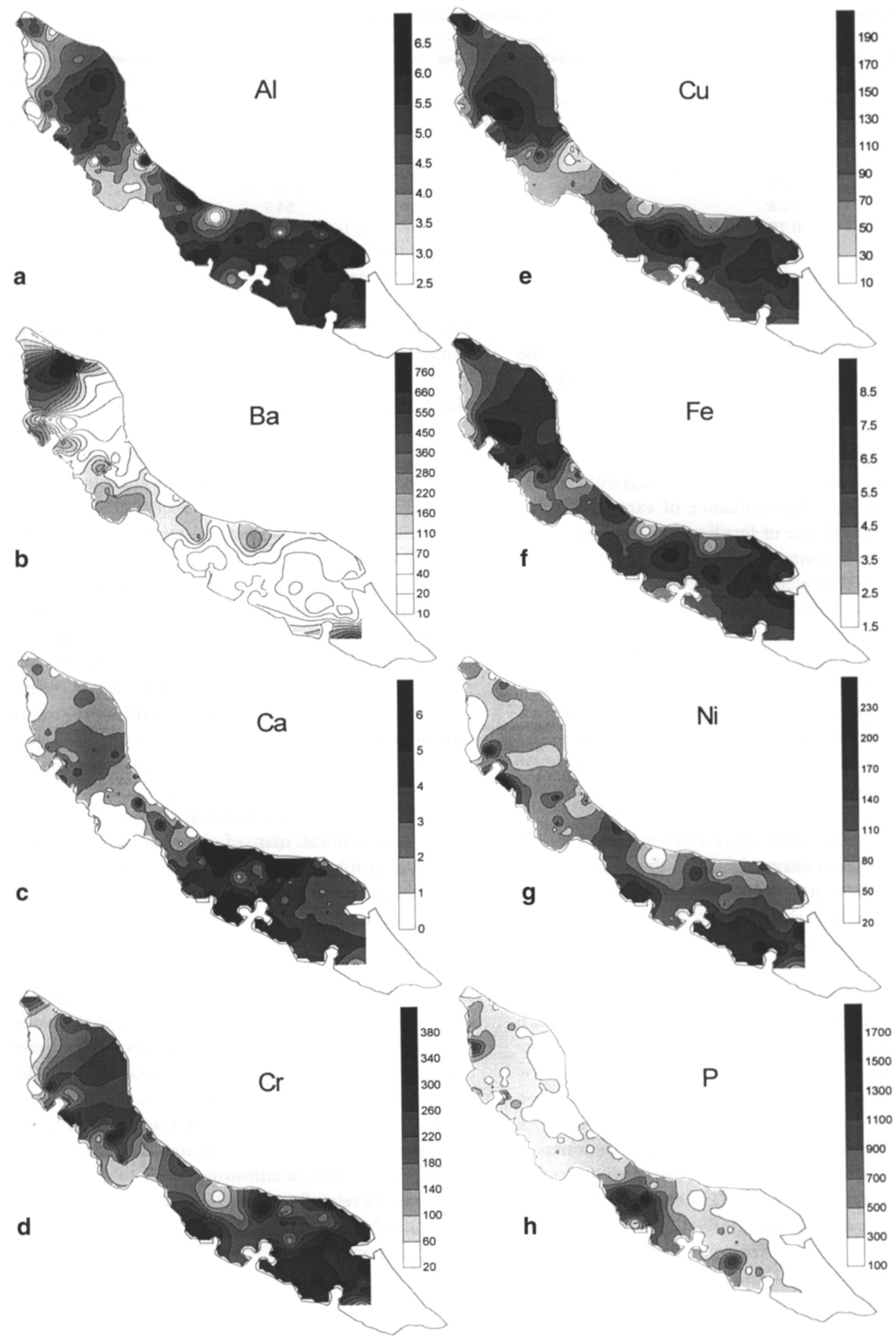

Fig. 3. Geochemical maps of some selected elements.

a: Al; b: Ba; c: Ca; d: Cr; e: Cu; f: Fe; g: Ni; h: P. 
dominance of the weathered soils of basalt origin. The map of the element, $\mathrm{Ca}$ (Fig 3c), reflects mainly the presence of limestone (fragments) in shallow soils. Low Ca-concentration patterns are found where the SL soil type is present and in soil-sampling sites from Midden Curaçao Formation origin in the middle part of the island. The $\mathrm{Mg}$ patterns reflect the dominance of high levels in the southeastern part of the island, which may be the result of higher contents of minerals like olivine and anorthite. Another explanation is the presence of dolomite as a consequence of more arid conditions in the eastern part of the island.

On the geochemical maps of $\mathrm{Mn}$ and Fe (Fig. 3f), high levels are found in the northwestern part of the island where the BW soil type is most dominant. In the eastern part of the island, the trace element $\mathrm{Sr}$ seems to be related to the areas of the more higher levels of $\mathrm{P}$ (Fig. 3h). The important trace elements $\mathrm{Co}, \mathrm{Cr}$ and also $\mathrm{Ni}$ (Fig. 3d, 3g) reflect - as a result of their dominance in soils from basaltic origin - the distribution pattern on their geochemical maps. Therefore, low levels can be found in the middle part of Curaçao.

\section{Background levels (baseline data)}

Significant natural correlations still occur, fortunately, between some of the elements within all of the defined geochemical soil types. Background levels (baseline data) have therefore been prepared from the entire geochemical data set of the soil types of Curaçao for environmental application for all soils. The Dutch background levels (the former $\mathrm{A}$ values) for metals are functions of lutum (particles $<2 \mu \mathrm{m}$ ) and organic-matter content in the soil, as known from the Dutch $A B C$ reference list for soil and groundwater contamination (VROM, 1989). The considerable difference of parent material, geochemical and soil processes between Dutch and Curaçao soils has, however, lead to a different approach. Regression analysis was carried out between some elements (a.o., the heavy metals) and the $\mathrm{Fe}$ or $\mathrm{Al}$ content of the $\mathrm{Cu}$ raçao soils. These correlations reflect the presence of some dominant primary and/or secondary minerals in the Curaçao soils. The regression equation can be useful to establish background values for future soil surveys. For the soils of Curaçao, these equations for background levels (baseline data) are presented in Table 8, accompanied with a precision interval (at 95 $\%$ confidence level). The soils of Curaçao might be contaminated if compounds are present at higher concentrations than expected from the baselines and precision interval. The low correlation coefficients for $\mathrm{Ba}$ and $\mathrm{Fe}$, as well as for $\mathrm{Zn}$ and $\mathrm{Fe}$ (Table 8), reflect the importance of other influences than $\mathrm{Fe}$.

\section{Discussion}

To start from general geological characteristics is not sufficient for geochemical soil characterization. It is important to consider all specific geochemical characteristics and processes first. Therefore, an approach purely based on the variation of geochemical composition has been used for defining the soil types of $\mathrm{Cu}-$ raçao. As a result, the defined soil types with contrasting geochemical characteristics include soil-sampling sites from the same geological formations. The numerous alterations performed on these soils by geochemical and soil-forming processes, in combination with influences from agriculture and their original mineralogy (parent material), are reflected in their chemistry in such a way that these soils have become homogeneous (geochemical) groups. The geochemical composition and characteristics of the defined soil types are of prime concern for the environmental values and perception, and also explain why these have been used as starting point for the present soil study.

The SL soil type includes sampling sites from only the limestone formation and the Knip Group. No soil-sampling sites from the other geologic formations have a geochemical composition that resembles this soil type. Due to the sandy texture, water infiltration will be rapid.

The MC soil type consists mostly of soil-sampling sites from the Midden Curaçao Formation (63\%). Two saliña's (saline soils) and a few sampling sites from the erosional Middle Limestone Terrace are also included. Top soils from the Midden Curaçao Formation are dominated by yellowish brown, shallow soils and consist of much unconsolidated gravel and stones (also present on the surface). Some of these soil-sampling sites are located on (low) slopes. A restricted drainage as a result of runoff rainwater leads to erosion of weathered material from the surface. This may work as a negative feedback for weathering because any advance resulting from these processes is retarded by the erosion process (Beckmann et al., 1974). The restricted drainage is therefore probably a predominant factor regarding the geochemical composition of this soil type. The other soil-sampling sites are from the rock lands of the eroded Limestone Terrace, according to the soil and soil-potential maps (Grontmij \& Sogreah, 1968). The high $\mathrm{Ba}$ and $\mathrm{Zn}$ contents are mostly a result of the contribution of Midden $\mathrm{Cu}$ raçao Formation sampling sites. $\mathrm{Ba}$ is a common element that is accumulated in acid rocks.

Within the A/C soil type, sampling sites from the limestone formation are from the Lower Limestone 
Terrace only. They are characterized as light yellow/ orange, sandy/silty soils with high Ec values (accompanied by high $\mathrm{Na}$ contents). Most Ec values exceed $1 \mathrm{mS} / \mathrm{cm}$, which defines the soils as being arid. Some Ec values of soil samples even exceed $4 \mathrm{mS} / \mathrm{cm}$ and therefore can be classified as saline soils (Bresler et al., 1982). Salt accumulations in the topsoils (salinization) explain these high Ec levels. They are probably caused by sea spray. The soils from Midden $\mathrm{Cu}-$ raçao Formation origin can be described as lightbrown soils from the valleys. Soils originating from the basalt formation are almost entirely located in the western part of the island. They are associated with the least weathered basaltic soils. This soil type contains light brown or orange soils with a sandy/silty texture. The AC soil type contains mostly soils from the limestone formation (38\%), Midden Curaçao Formation (23\%) and Basalt West Formation (29\%).

The BW soil type shows no clear relationship with one specific geological formation as the soils originate from different geological formations. Only because of a slight dominance of soils originating from the Basalt West Formation (55\%), this soil type is labelled as the $\mathrm{BW}$ soil type. Almost a fourth part $(23 \%)$ is from the limestone formation. This soil type can mostly be described as orange-brown, silty loam soils.

The AI soil type consists, with the exception of one soil sampling site in a basalt mangrove forest (near a land house), of agricultural soils and gardens with a basalt formation origin. They are described as brown alluvial soils. The composition of this soil type is influenced by (intense) agricultural activities, such as addition of manure and/or fertilizer and supply of additional water through irrigation. The extreme $\mathrm{Zn}$ level of one soil sampling site (more than $500 \mathrm{ppm} \mathrm{Zn}$ ) is probably a single trace-element anomaly due to local pollution. A possible source of zinc pollution are galvanized pipes that are often used for water supply. Like the BW soil type, the $\mathrm{Cu}$ content of the AI soil type also exceeds the Dutch $B$ value for soils and both element levels of $\mathrm{Cr}$ and $\mathrm{Ni}$ exceed the $\mathrm{B}$ values as well.

About $57 \%$ of the soil-sample sites of the $\mathrm{BE}$ soil type are on the Basalt East Formation, and $24 \%$ on the Basalt West Formation. Ni and Co are typical elements of basic and ultrabasic rocks (Vinogradov, 1959). Ni occurs in primary minerals as isomorphic substitution for $\mathrm{Fe}$ in olivines, pyroxenes, amphiboles, spinel and micas (Sposito, 1989). Co is found as isomorphic substitutions for $\mathrm{Mn}$ in oxides and for $\mathrm{Fe}$ in pyroxenes, amphiboles and micas. The high amounts of these elements in this Basalt East soil type are easily explained by the origin of parent material for most of the soil-sampling sites (weathered basalt). Cr oc- curs, like $\mathrm{Ni}$, mainly concentrated in the ultrabasic rocks and to a lesser extent in basic rocks. The distribution in soils depends strongly on the character of the underlying rocks (Vinogradov, 1959). For these soil samples, an association is observed between Co and $\mathrm{Mn}$, as found in the BW soil type. This soil type can be described as orange-brown, sandy loam soils. The $\mathrm{Cu}$ content of this soil type also exceeds the Dutch B value $(100 \mathrm{ppm})$. The levels of the trace elements $\mathrm{Cr}$ and $\mathrm{Ni}$ are both high and above their $\mathrm{B}$ values as well.

It seems that the Ca content of the soils is not of great influence on the clustering of the soils. It generally shows a large variation within one characteristic soil type. The presence of small pieces of calcite rock in some soil samples may be an explanation for this observation. Another explanation may be that calcification is a subdominant process that is active within each soil type.

The difference in chemical composition of soils originating from the Basalt East and the Basalt West Formations has resulted into two soil types with 'basaltic' characteristics. The most distinct differences are the higher $\mathrm{Cr}$ and $\mathrm{Ni}$ contents of the BE soil type, and the higher $\mathrm{K}$ en $\mathrm{V}$ contents of the BW soil type. The differences in soil composition reflect probably differences of the original bedrock composition (mineralogy) between the divided Basalt East and the Basalt West part of the island.

The aqua regia extraction of the soil samples is not a total analysis but rather reflects differences in the element contents of minerals of the same extractability and/or their contents in the soil. The SL soil type consists of low $\mathrm{Al}$ and $\mathrm{Fe}$ contents next to low trace-element contents. According to field data, most of the soil-sampling sites assigned to this soil type can be characterized as sandy soils. From the determination of extraction efficiencies for the elements $\mathrm{Al}, \mathrm{Fe}, \mathrm{Mg}$ and $\mathrm{Mn}$ (from total analysis in combination with an analysis after a - heated - concentrated $\mathrm{HNO}_{3}$ extraction method), the lowest contents were found in sandy soils; clayey soils provided higher values (Edelman, 1983). This may also explain the low element contents of the SL soil type after aqua regia extraction.

The $\mathrm{BE}$ (high $\mathrm{Ca}$ and $\mathrm{Mg}$ contents) and $\mathrm{MC}$ (K-rich) soil types have a high potential as natural fertilizers. An important soil-quality threat is manifested in the AI soil type. The contrasting chemical signature of the AI soil type with the other soil types of Curaçao shows probably the impact of industrial fertilizers and/or manure on soil composition. Further unrestricted use of industrial fertilizers may lead to an increase of this soil type on the island. Possible environmental damage to soils due to this impact is yet un- 
clear. As a consequence, the vulnerability of the Curaçao soils needs further investigation. When fertilizers are applied to soils with a coarse soil texture (rapid water infiltration), groundwater is also vulnerable for contamination by the fertilizers and other agricultural chemicals. Nitrate pollution of the groundwater is one of the important findings of a groundwater study on Curaçao (Louws et al., 1997; Van Sambeek et al., 2000 - this issue). This pollution exceeds the Dutch standard for drinking water $(50 \mu \mathrm{g} / 1)$ and the relating wells are mainly located on agricultural land and gardens in (sub)urban areas. The nitrate pollution is explained by the possible impact on the phreatic aquifers of cesspits and use of fertilizers. Considering the results of this soil survey, salt accumulation in topsoils may be the most common pollution of the soil types of Curaçao.

Regarding to the environmental impact of fertilizers on the soils of Curaçao, there are probably also some alternative ways towards solving agricultural and environmental problems at the same time. Because of their high potential as natural fertilizers, a mixture between soils of the $\mathrm{BE}$ soil type (high $\mathrm{Ca}$ and $\mathrm{Mg}$ contents), the $\mathrm{MC}$ soil type (K-rich) and/or P-rich limestone would yield a mixed soil with better agricultural quality.

\section{Conclusions}

Based upon the geochemical composition, the soils of the semi-arid island of Curaçao have been divided into geochemical soil types with contrasting signatures, using fuzzy c-means clustering combined with nonlinear mapping. The soils can be grouped into six geochemical soil types. Labelled according to their most striking characteristic (element content, dominant geology, soil process, etc.), the six soil types of Curaçao are:

- sandy limestone soil type (SL): orange-brown soils, sandy texture, easily leached, resistant minerals, lowest content of the major elements, aluminum, iron, calcium and magnesium, and low trace-elements contents;

- Midden Curaçao soil type (MC): yellow-brown shallow soils, slightly weathered, much unconsolidated gravel, high potassium contents, maximum barium, potassium, lithium and zinc contents;

- arid/calcareous soil type (AC): light brown or orange soils, sandy/silty texture, arid to saline soils, porous and calcareous, higher calcium, magnesium and titanium contents (10 times) than the MC soil type;

- Basalt West soil type (BW): orange-brown, silty loam soils, mostly related to the Basalt West Forma- tion, characterised by maximum contents of the major element iron and of the trace elements cobalt, copper, manganese, titanium and vanadium;

- agriculture-influenced soil type (AI): brown, relatively deep agricultural soils or gardens, alluvial soils, composition shows high contents of calcium, magnesium, sodium, phosphorus and strontium, soils are influenced by irrigation and the addition of manure and fertilizers;

- Basalt East soil type (BE): orange-brown, sandy loam soils, mostly related to the Basalt East Formation, characterised by the maximum aluminum and chromium contents, high calcium, magnesium, nickel and cobalt contents, and the lowest potassium content (difference of $1,800 \mathrm{ppm}$ with BW soil type).

The homogeneous grouping resulting from cluster analysis only partly reflects differences in bedrock composition, as soil samples from the same geological formation show large differences in geochemical composition. It explains an important part of the chemical composition, but a different division of soil types is found as a result of numerous alterations of these soils by geochemical and soil-formation processes like weathering, erosion and pollution.

The present geochemical soil survey and the produced geochemical maps of Curaçao demonstrate the natural variations of the soil composition on the island. They provide a basis for environmental studies and issues on the island. Background levels (baseline data) have been prepared from the entire data set of the geochemical composition of the soils for several elements, taking into consideration a strong correlation with the $\mathrm{Fe}$ or $\mathrm{Al}$ content of these soils. The defined baselines can be used to establish background values for future soil surveys.

An important threat for the soil quality is manifested in the AI soil type. Its contrasting chemical signature shows probably the impact of industrial fertilizers and/or manure on soil composition. Nitrate pollution of groundwater on agricultural sites and gardens is one of the important findings of a groundwater study on Curaçao. Considering the relationship between these two threatening issues, this emphasizes the environmental impact of unrestricted use of industrial fertilizers and/or other chemicals on both the soils and groundwater of Curaçao.

\section{Acknowledgement}

The present soil-survey forms part of an overall geochemical survey of the Leeward Netherlands Antilles by the Institute of Earth Sciences of Utrecht University. The soil survey has been made possible thanks to 
help, assistance and suggestions by the following persons: R. Louws, R. de Bruine, L. Eijsinck, S. Vriend and $\mathrm{K}$. Hendriks. The CARMABI institute and $\mathrm{Mr}$. Bakhuis are thanked for the use of the laboratory facilities and for their friendly accommodation. Many thanks go to C. Winkel (Dienst Landbouw, Veeteelt \& Visserij, Willemstad) for all advice, help and assistance during the soil survey on the island. G. Klaver, L. Pors and Mr. Tikolas (Milieudienst, Willemstad) are also thanked for their useful information about the island, including its geology. A. Steenfeld and C. Wiedeman are especially thanked for their critical review, which greatly improved the manuscript.

\section{References}

Alam, M., 1977. Awa Marga, landbouw en water op Curaçao. $\mathrm{Ph} . \mathrm{D}$. thesis Wageningen: $57 \mathrm{pp}$.

Beckmann, G.G., Thompson, C.H. \& Hubble, G.D., 1974. Genesis of red and black soils on basalt on the Darling Downs, Queensland, Australia. Journal of Soil Science 25: 265-281.

Beets, D.J., 1972. Lithology and stratigraphy of the Cretaceous and Danian successions of Curaçao. Ph.D. thesis University of Amsterdam: $153 \mathrm{pp}$.

Beets, D.J. \& MacGillavry, H.J., 1977. Outline of the Cretaceous and Early Tertiary history of Curaçao, Bonaire and Aruba. In: Guide to the field excursions on Curaçao, Bonaire and Aruba. GUA Papers of Geology, Series 1, 10: 1-6.

Bresler, E., McNeal, B.L. \& Carter, D.L., 1982. Saline and sodic soils - principles, dynamics, modeling. Advanced Series in Agricultural Sciences. Springer-Verlag (New York): 167-227.

Breteler, H.G.M., 1981. Geschiktheid voor akkerbouw, tuinbouw en grasland, de beste gronden van Curaçao, herinterpretatie van de klassen 1 en 2 van de bodemgeschiktheidskaart van het Grontmij \& Sogreah rapport (1968). Wageningen: $21 \mathrm{pp}$.

De Vivo, B., Boni, M., Marcello, A., Di Bonito, M. \& Russo, A., 1997. Baseline geochemical mapping of Sardinia (Italy). Journal of Geochemical Exploration 60: 77-90.

Edelman, Th., 1983. Achtergrondgehalten van een aantal anorganische en organische stoffen in de bodem van Nederland, een eerste verkenning. Ministerie VROM (Den Haag): $65 \mathrm{pp}$.

Grontmij \& Sogreah, 1968. Water and land resources development plan for the islands of Aruba, Bonaire and Curaçao. Wageningen: $98 \mathrm{pp}$.
Hamilton, R., 1941. Bijdrage tot de bodemkundige kennis van Nederlands West-Indië, Tropengronden 1: $55 \mathrm{pp}$.

Hieltjens, A.H.M. \& Breeuwsma, A., 1983. Chemische bodemonderzoek-methoden voor bodemkenmerken en anorganische stoffen. Ministerie van VROM (Den Haag): 65 pp.

Klaver, G.Th., 1987. The Curaçao lava formation; an ophiolitic analogue of the anomalous thick layer 2B of the Mid-Cretaceous oceanic plateaus in the Western Pacific and Central Caribbean. GUA Papers of Geology 27: $168 \mathrm{pp}$.

Loughnan, F.C., 1969. Chemical weathering of the silicate minerals. American Elsevier Publishing Company (New York): 145 pp.

Louws, R.J., Vriend, S.P. \& Frapporti, G., 1997. De grondwaterkwaliteit van Curaçao. Een hydrogeochemisch onderzoek. $\mathrm{H}_{2} \mathrm{O}$ 30: 788-791.

Mitchell, J.K., 1993. Fundamentals of soil behaviour. Wiley (New York): $437 \mathrm{pp}$.

Salminen, R. \& Tarvainen, T., 1997. The problem of defining geochemical baselines. A case study of selected elements and geological materials in Finland. Journal of Geochemical Exploration 60: 91-98.

Sposito, G., 1989. The chemistry of soils. Oxford University Press (New York): 281 pp.

Steila, D., 1976. The geography of soils: formation, distribution and management. Prentice-Hall (New Jersey): $22 \mathrm{pp}$.

Stienstra, P., 1983. Structure and general chemistry of Table Mountain Santa Barbara phosphates, Curaçao, Netherlands Antilles. Geologie \& Mijnbouw 62: $275-284$.

STINAPA, 1977. Guide to the field excursions on Curaçao, Bonaire and Aruba, Netherlands Antilles. GUA Papers of Geology, Serie 1, 10: 120 pp.

Van Breemen, N. \& Brinkman, R., 1976. Chemical equilibria and soil formation. In: Bolt, G.H. \& Bruggenwert, M.G.M. (eds.): Soil chemistry, A. Basic elements. Elsevier Scientific (Amsterdam): 141-170.

Van Sambeek, M.H.G., Eggenkamp, H.G.M \& Vissers, M.J.M., 2000. The groundwater quality of Aruba, Bonaire and Curaçao: a hydrogeochemical study. In: Gaans, P.F.M. \& Vriend, S.P. (eds.): Geochemical mapping in the Kingdom of the Netherlands. Geologie en Mijnbouw / Netherlands Journal of Geosciences 79 (4): 459-466 (this issue).

Vinogradov, A.P., 1959. The geochemistry of rare and dispersed chemical elements in soils. New York Consultance Bureau (New York): 209 pp.

VROM, 1989. Leidraad Bodemsanering. Ministerie van VROM (Den Haag): 90 pp.

Young, A., 1976. Tropical soils and soil survey. Cambridge Geographical Studies 9:468 pp. 